\title{
KARAKTERISTIK ORANGTUA DAN LINGKUNGAN RUMAH MEMPENGARUHI PERKEMBANGAN BALITA
}

\author{
Agrina $^{1,2^{*}}$, Junaiti Sahar ${ }^{3}$, Rr. Tutik Sri Haryati ${ }^{3}$ \\ 1. PSIK Universitas Riau Departemen Keperawatan Jiwa dan Komunitas, Riau 28231, Indonesia \\ 2. Program Studi Magister Ilmu Keperawatan Universitas Indonesia, Depok 16424, Indonesia \\ 3. Fakultas Ilmu Keperawatan Universitas Indonesia, Depok 16424, Indonesia \\ *Email:ayang_shr@yahoo.co.id
}

\begin{abstract}
Abstrak
Pertumbuhan dan perkembangan balita memerlukan stimulasi yang adekuat dari orangtua dan lingkungan sekitarnya. Bila stimulasi tidak adekuat maka pertumbuhan dan perkembangan balita mengalami gangguan. Tujuan penelitian mengetahui pengaruh karakteristik orangtua dan lingkungan rumah terhadap perkembangan balita. Disain penelitian deskriptif korelasi dengan pendekatan cross sectional dengan sampel 98 orang dipilih secara proporsional cluster sampling di wilayah kerja sebuah Puskesmas Sidomulyo Rawat Inap di Pekanbaru. Pengumpulan data dengan kuisioner, analisis dengan chi square dan regresi logistik berganda. Hasil penelitian menunjukkan bahwa adanya pengaruh pekerjaan bapak dan lingkungan fisik terhadap perkembangan balita dengan lingkungan fisik sebagai variabel dominan $(\mathrm{p}=0,029 ; \alpha=0,05)$. Peneliti merekomendasikan agar keluarga mendapat sosialisasi mengenai bagaimana cara menciptakan lingkungan fisik yang penuh stimulasi, guna mencapai perkembangan balita yang optimal.
\end{abstract}

Kata kunci: karakteristik orangtua, lingkungan rumah, perkembangan balita

\begin{abstract}
Growth and development of toddlers require adequate stimulation from the parents and the surrounding environment. When stimulation is inadequate then the growth and development of young children experiencing problems. Research objectives determine the effect of parental characteristics and home environment on early childhood development. Descriptive correlation study design with cross-sectional approach with a sample of 98 people selected by proportional cluster sampling in a work area Sidomulyo Health Center Inpatient at Pekanbaru. Collecting data by questionnaire, with a chi square analysis and multiple logistic regression. The results showed the influence of the father works and the physical environment of early childhood development with the physical environment as the dominant variable ( $p=0,029 ; \alpha=0,05)$. Researchers recommend that families get the socialization of how to create a physical environment that is full of stimulation, in order to achieve optimal early childhood development.
\end{abstract}

Keywords: parents characteristics, home environment, under five children development

\section{Pendahuluan}

Pertumbuhan dan perkembangan balita memerlukan perhatian yang lebih khusus, yakni stimulasi dini yang adekuat dari lingkungan sekitarnya dan orangtua. Bila proses stimulasi tidak adekuat maka pertumbuhan dan perkembangan pada masa balita ini mengalami gangguan. Hal ini akan mengakibatkan terganggunya persiapan terhadap pembentukan anak yang berkualitas di masa yang akan datang.

Menurut Potter dan Perry (2005), yang menyatakan bahwa kemampuan seorang anak untuk melewati setiap tahap perkembangan akan mempengaruhi status kesehatannya secara holistik. Kesuksesan atau kegagalan yang dialami dalam satu fase akan mempengaruhi kemampuan anak untuk menyelesaikan fase-fase selanjutnya.

Friedman (2003) menyampaikan bahwa tugas perkembangan keluarga dengan balita (pra sekolah) diantaranya membantu anak bersosialisasi dan melakukan stimulasi tumbuh kembang anak. Pada saat ini, dibutuhkan kondisi rumah yang cukup adekuat untuk proses perkembangannya. Secara fisik perlu disediakan sarana dan media seperti alat permainan sesuai umur balita, 
peralatan rumah tangga yang aman, serta ruang yang leluasa bagi anak untuk bergerak saat mengeksplorasi lingkungannya. Dengan kata lain, keluarga memiliki tugas menciptakan lingkungan yang adekuat bagi balita guna mencapai perkembangan optimal sesuai dengan usianya.

Hasil penelitian yang dilakukan oleh tim riset kesehatan anak dan perkembangan anak (NICHD) (2000) menunjukkan bahwa adanya perbedaan hasil perkembangan balita antara lingkungan rumah yang memiliki keterbatasan sumber dan kesempatan belajar dan rumah yang penuh dengan stimulasi dari lingkungannya. Keterbatasan sumber belajar dapat dikaitkan dengan kondisi sosial ekonomi (pendapatan orangtua), pendidikan orangtua, dan status pekerjaan. Menurut Ball dan Bindler (1995), yang menjelaskan bahwa sejumlah faktor yang berkaitan dengan perkembangan anak terkait dengan sosial ekonomi yang rendah. Berdasarkan penelitian tersebut, dapat disimpulkan bahwa karakteristik orangtua berkontribusi dalam perkembangan balita.

Data kependudukan Kecamatan Tampan tahun 2007 menggambarkan kondisi sosial ekonomi di wilayah kerja Puskesmas Sidomulyo Rawat Inap masih berstatus menengah ke bawah. Status gizi kurang pada anak pada 2006 merupakan yang tertinggi di Kota Pekanbaru (149 kasus gizi kurang dan 30 kasus gizi buruk) (Dinas Kesehatan Provinsi Riau, 2007).

Sementara itu, keadaan perkembangan pada balita umumnya tidak diketahui secara pasti karena tidak ada kegiatan pemantauan perkembangan balita. Tanuwijaya (2002) menyebutkan bahwa perkembangan seorang anak berkorelasi dengan pertumbuhannya, dimana apabila seorang anak terganggu pertumbuhannya dalam hal ini mengalami gizi kurang, maka kemungkinan akan mengalami gangguan perkembangan pula.

Berdasarkan uraian dan fenomena di atas, peneliti tertarik untuk melakukan penelitian tentang pengaruh karakteristik orangtua dan lingkungan rumah terhadap perkembangan balita di wilayah kerja sebuah Puskesmas Sidomulyo Rawat Inap Kota Pekanbaru. Penelitian bertujuan mengetahui pengaruh karakteristik orangtua dan lingkungan rumah terhadap perkembangan balita.

\section{Metode}

Desain penelitian yang digunakan adalah deskriptif korelasi dengan pendekatan cross sectional. Sampel adalah 98 orangtua yang memiliki balita dan tinggal di wilayah kerja sebuah Puskesmas Sidomulyo rawat inap Pekanbaru. Teknik pengambilan sampel dengan proportional cluster sampling.

Alat pengumpul data adalah kuesioner. Sebelumnya telah dilaksanakan uji coba kuesioner di wilayah kerja sebuah Puskesmas Sidomulyo Pekan baru. Pemilihan tempat uji coba karena wilayah Puskesmas Sidomulyo memiliki kesamaan karakteristik. Pengambilan data dilakukan selama tiga minggu (minggu I sampai III Mei 2008). Data dianalisis menggunakan analisis univariat, bivariat (chi square), dan multivariat (regresi logistik berganda).

\section{Hasil}

Berdasarkan tabel 1, karakteristik orangtua yang terlibat dalam penelitian ini adalah sebagian besar memiliki latar belakang pendidikan rendah (SD SMA), bapak bekerja formal, sedangkan ibu tidak bekerja, dan pendapatan keluarga berada diatas UMP ( $>$ Rp800.000,-). Gambaran lingkungan rumah baik fisik maupun psikologis mayoritas tidak mendukung, seperti yang terlihat pada tabel 2 .

Hasil penelitian menunjukkan bahwa jenis pekerjaan bapak dan lingkungan fisik berhubungan secara bermakna dengan perkembangan balita ( $\mathrm{p}=$ $0,039$ dan $p=0,025 ; \alpha=0,05)$. Keterangan lengkap dapat dilihat pada tabel 3.

Tabel 3 menunjukkan bahwa bapak yang bekerja formal dan mempunyai balita yang perkembangannya tidak sesuai umur sebanyak 70,2\%. 
Tabel 1. Karakteristik Responden

\begin{tabular}{lcc}
\hline \multicolumn{1}{c}{ Karakteristik Orangtua } & n & (\%) \\
\hline Pendidikan Bapak: & & \\
$\quad$ Rendah (SD-SMA) & 77 & 78,6 \\
Tinggi (PT) & 21 & 21,4 \\
& & \\
Pendidikan Ibu: & 81 & 82,7 \\
$\quad$ Rendah (SD-SMA) & 17 & 17,3 \\
$\quad$ Tinggi (PT) & & \\
& & 41,8 \\
Pekerjaan Bapak: & 41 & 58,2 \\
$\quad$ Informal & 57 & \\
$\quad$ Formal & & 85,7 \\
Pekerjaan Ibu: & 84 & 14,3 \\
$\quad$ Tidak bekerja & 14 & 17,3 \\
Bekerja & & 82,7 \\
Pendapatan/bulan: & 17 & \\
$\quad$ <MP & 81 & \\
$\quad$ UMP & & \\
\hline
\end{tabular}

Persentase tersebut lebih rendah daripada bapak yang bekerja informal $(87,8 \%)$ yang memiliki anak dengan perkembangan yang tidak sesuai umur. Hasil uji statistik menunjukkan bahwa ada pengaruh secara bermakna antara pekerjaan bapak dengan perkembangan balita $(p=0,039 ; \alpha=0,05)$. Analisis keeratan hubungan dua variabel menunjukkan nilai $\mathrm{OR}=3,060$, artinya adalah bapak yang bekerja informal mempunyai peluang terjadinya perkembangan balita yang tidak sesuai dengan usianya sebesar 3,060 kali dibandingkan bapak yang bekerja formal.

Tabel 3 menggambarkan data bahwa sebanyak $66,7 \%$ balita yang perkembangannya tidak sesuai umum berada di lingkungan fisik yang mendukung. Sedangkan, 85,7\% balita di lingkungan fisik yang tidak mendukung mengalami perkembangan yang tidak sesuai dengan usianya. Hasil uji statistik menunjukkan bahwa ada pengaruh yang bermakna antara lingkungan fisik dengan perkembangan balita $(p=0,025 ; \alpha=$ $0,05)$. Analisis keeratan hubungan dua variabel didapatkan $\mathrm{OR}=3,000$, artinya adalah lingkungan fisik yang tidak mendukung mempunyai peluang terjadinya perkembangan balita yang tidak sesuai dengan usianya sebesar 3,000 kali dibanding dengan lingkungan fisik yang mendukung.

Berdasarkan hasil analisis multivariat ditemukan bahwa variabel lingkungan fisik yang paling besar pengaruhnya terhadap perkembangan balita $(\mathrm{p}=$ $0,029 ; \alpha=0,05 ; \mathrm{OR}=3,000)$, dimana hal ini berarti bahwa lingkungan fisik yang mendukung akan mempengaruhi perkembangan balita sesuai umur sekitar 3 kali lebih besar dibandingkan dengan lingkungan fisik yang tidak mendukung.

\section{Pembahasan}

Berdasarkan hasil penelitian didapatkan bahwa pekerjaan bapak dan lingkungan fisik berpengaruh terhadap perkembangan balita. Namun, variabel karakteristik lain seperti pendidikan bapak, pendidikan ibu, pekerjaan ibu, pendapatan orangtua, dan lingkungan psikologis tidak ada pengaruh terhadap perkembangan balita. Hasil analisis juga menemukan bahwa lingkungan fisik paling besar pengaruhnya terhadap perkembangan balita. 
Tabel 2. Lingkungan Rumah Responden

\begin{tabular}{lll}
\hline \multicolumn{1}{c}{ Lingk ungan Rumah } & $\mathbf{n}$ & $\mathbf{( \% )}$ \\
\hline Lingkungan Fisik & 56 & 57,1 \\
Tidak Mendukung & 42 & 42,9 \\
Mendukung & & \\
Lingkungan Psikologis & 59 & 60,2 \\
Tidak Mendukung & 39 & 39,8 \\
\hline Mendukung & \\
\hline
\end{tabular}

Hasil penelitian yang dilakukan oleh tim riset kesehatan anak dan perkembangan anak (NICHD) (2000), yang menyatakan bahwa adanya perbedaan hasil perkembangan balita antara lingkungan rumah memiliki keterbatasan sumber dan kesempatan belajar dengan rumah yang penuh dengan stimulasi dari lingkungannya. Keterbatasan sumber belajar dapat dikaitkan dengan kondisi sosial ekonomi yang kurang.

Kesempatan belajar dan rumah yang penuh dengan stimulus identik dengan tersedianya fasilitas kegiatan stimulus, seperti tersedianya alat permainan yang sesuai dengan usianya. Tersedianya media stimulus tentunya membutuhkan kondisi status ekonomi yang cukup ditambah adanya peran serta dari orangtua untuk melakukan stimulasi perkembangan pada balitanya.

Kemampuan orangtua, terutama ialah seorang ibu dalam menstimulus balita tidak bisa muncul begitu saja. Menurut hasil penelitian Redjeki (2005), yang menyatakan bahwa bahwa kemampuan ibu menstimulus balita terjadi karena pemberian pendidikan kesehatan yang diberikan dengan materi yang cukup sederhana dan metoda yang tepat. Peningkatan kemampuan ibu dapat dilihat dari peningkatan pengetahuan, sikap dan perilaku dalam menstimulus balita.

Artinya pengetahuan ibu tentang bagaimana menciptakan lingkungan rumah yang penuh stimulus tidak secara otomatis ada namun didapat melalui proses pendidikan kesehatan tentang stimulasi perkembangan dengan menggunakan materi dan metoda yang tepat.
Hasil penelitian oleh Saadah (2004), yang menemukan bahwa terdapat perbedaan perkembangan balita usia 3-18 bulan antara yang menggunakan buku KIA dengan yang tidak menggunakan buku KIA $(p=0,002 ; \alpha=0,05)$. Artinya tidak adanya pengaruh antara pendidikan ibu dan perkembangan balita pada penelitian ini disebabkan karena ibu belum pernah mendapat pendidikan kesehatan tentang bagaimana menciptakan lingkungan rumah yang penuh stimulus terhadap balita dan tidak memiliki buku panduan tentang perkembangan balita.

Stimulasi pada balita harus dilakukan secara terus menerus dan pada setiap kesempatan. Keberadaan ibu disamping balita dibutuhkan untuk melakukan stimulasi pada balita. Menurut Handayani (2003), menjelaskan bahwa ibu yang bekerja akan berakibat pada kurangnya waktu kebersamaan antara ibu dan anak, akan tetapi ibu harus mampu meluangkan waktu untuk bersama dengan anak untuk membimbingnya, berkomunikasi, bercanda, dan lain sebagainya.

Hal yang sama juga terjadi pada ibu yang tidak bekerja. Ibu harus bisa membagi waktu untuk bersama dengan anak. Hal ini berarti bahwa tidak mutlak ibu yang ada di rumah (tidak bekerja) akan menjamin perkembangan balita sesuai dengan umur.

Handayani (2003) mengatakan bahwa penyebabnya adalah banyak ibu yang tidak bekerja dan seharian di rumah namun hubungan dan pendidikan balitanya kurang baik. Hal ini terjadi karena secara fisik ibu berada dan bersama anak namun ibu tidak terlibat dalam proses stimulasi dengan balita. 
Tabel 3. Hubungan antara Karakteristik Orangtua dan Lingkungan Rumah terhadap Perkembangan Balita

\begin{tabular}{|c|c|c|c|}
\hline \multicolumn{2}{|c|}{ Variabel } & \multirow{2}{*}{$\begin{array}{c}\text { Perkembangan Balita Tidak Sesuai Umur } \\
66,7 \% \\
80,5 \%\end{array}$} & \multirow{2}{*}{$\frac{\mathbf{p}}{0,237}$} \\
\hline Pendidikan Bapak & $\begin{array}{l}\text { Tinggi } \\
\text { rendah }\end{array}$ & & \\
\hline Pendidikan Ibu & $\begin{array}{l}\text { Tinggi } \\
\text { rendah }\end{array}$ & $\begin{array}{l}70,6 \% \\
79,0 \%\end{array}$ & 0,524 \\
\hline Pekerjaan Bapak & $\begin{array}{l}\text { Formal } \\
\text { Informal }\end{array}$ & $\begin{array}{l}70,2 \% \\
87,8 \%\end{array}$ & $\mathbf{0 , 0 3 9}$ \\
\hline Pekerjaan Ibu & $\begin{array}{l}\text { Tdk bekerja } \\
\text { Bekerja }\end{array}$ & $\begin{array}{l}75,0 \% \\
92,9 \%\end{array}$ & 0,181 \\
\hline Pendapatan Orangtua & $\begin{array}{l}<\mathrm{UMP} \\
>\mathrm{UMP}\end{array}$ & $\begin{array}{l}76,5 \% \\
77,8 \%\end{array}$ & 1,000 \\
\hline Lingkungan Fisik & $\begin{array}{l}\text { Mendukung } \\
\text { Tidak mendukung }\end{array}$ & $\begin{array}{l}66,7 \% \\
85,7 \%\end{array}$ & $\mathbf{0 , 0 2 5}$ \\
\hline Lingkungan Psikologis & $\begin{array}{l}\text { Mendukung } \\
\text { Tidak mendukung }\end{array}$ & $\begin{array}{l}7,44 \% \\
7,97 \%\end{array}$ & 0,538 \\
\hline
\end{tabular}

Hal tersebut berarti bahwa yang terpenting yaitu adanya cukup waktu (berkualitas) untuk bersama dengan anak untuk bermain dan melakukan stimulus yang adekuat pada balita baik pada ibu bekerja maupun tidak bekerja (ibu rumah tangga). Proses stimulasi membutuhkan media dan sarana belajar, seperti tersedianya alat permainan yang sesuai dengan usianya.

Menurut Ball dan Bindler (1995), bahwa salah satu faktor yang berkaitan dengan perkembangan balita yaitu terkait dengan sosial ekonomi yang rendah. Sosial ekonomi rendah identik dengan pendapatan yang rendah. Pada penelitian ini rata-rata pendapatan orangtua di wilayah kerja Puskesmas Sidomulyo Rawat Inap berada di atas UMP (> Rp800.000,-). Namun pendapatan perbulan keluarga ini kurang mempertimbangkan jumlah keluarga yang menjadi tanggungan. Oleh karena itu, bisa jadi pendapatannya berada di atas UMP (baik), namun pada hakikatnya pendapatannya kurang jika dinilai dari jumlah tanggungan keluarga. Pendapatan keluarga kurang maka penyediaan terhadap sumber belajar (alat-alat permainan) bagi balita sebagai sarana stimulasi akan terabaikan.
Lingkungan rumah yang kondusif juga dibutuhkan untuk perkembangan balita. Secara fisik dibutuhkan rumah yang penuh sarana dan prasarana bermain sesuai umur, keamanan perlu dijaga karena balita senang melakukan ekplorasi terhadap lingkungan, dan keterlibatan orangtua dalam stimulasi.

Lingkungan psikologis merupakan hal yang penting untuk perkembangan balita terutama perkembangan kepribadian balita. Kasih sayang dan perhatian merupakan kebutuhan psikologis bagi anak yang penting untuk perkembangan jiwa yang sehat (Markum, et al., 1991). Perilaku orangtua terhadap balita yang negatif, seperti memarahi, membentak, memukul, membatasi anak, dan lainlain akan mengakibatkan perkembangan balita terganggu. Menurut Sigmund Freud dalam Markum, et al. (1991), bahwa berbagai problem yang dihadapi penderita dewasa disebabkan oleh gangguan atau hambatan yang dialami selama perkembangan psikososialnya masa balita. Artinya lingkungan psikologis akan lebih memberi dampak kepada perkembangan kepribadian balita dibandingkan perkembangan motorik, bahasa, dan sosial yang menjadi perhatian pada penelitian ini. 
Pada penelitian ini terdapat beberapa keterbatasan seperti instrumen penelitian yang dikembangkan oleh peneliti sendiri yang kurang pengalaman, KPSP yang kurang seimbang dalam membagi penilaian perkembangan, jumlah sampel yang kurang memadai karena dibagi tiga kelompok umur balita, proses pengumpulan data karena banyak anak balita yang tidak mau dilakukan pemeriksaan (malu atau takut), dan hasil penelitian yang hanya dapat digeneralisir di wilayah kerja sebuah Puskesmas rawat inap di Pekanbaru.

\section{Kesimpulan}

Hasil penelitian yang dilakukan di wilayah kerja sebuah Puskesmas Sidomulyo Rawat Inap di Pekanbaru yang dilakukan pada 98 responden, yang menunjukkan hasil bahwa mayoritas pendidikan orangtua adalah rendah, pekerjaan bapak adalah formal, sedangkan ibu tidak bekerja (ibu rumah tangga), dan pendapatan keluarga berada diatas UMP. Lingkungan rumah baik fisik maupun psikologis mayoritas tidak mendukung. Berdasarkan uji statistik bivariat, diperoleh pekerjaan bapak dan lingkungan fisik yang dapat mempengaruhi perkembangan balita. Adapun lingkungan merupakan yang paling besar pengaruhnya terhadap perkembangan balita.

Peneliti menyarankan perlu dilakukan kegiatan deteksi tumbuh kembang secara berkala dan berkelanjutan, kunjungan rumah oleh perawat dan kader kesehatan secara rutin, pelatihan kader mengenai perihal melakukan deteksi dini dan stimulasi tumbuh kembang balita serta dilanjutkan kegiatan supervisi.

Posyandu yang peduli terhadap perkembangan balita dan perkumpulan atau kelompok ibu-ibu yang memiliki balita perlu dibentuk atau diadakan. Keluarga (ibu) perlu dibina dengan menggunakan metoda yang tepat tentang cara menciptakan lingkungan fisik yang penuh stimulasi dan menyediakan buku panduan perkembangan balita. Sarana bermain yang terjangkau beserta ketersediaan alat permainan yang sesuai umur dalam bentuk rumah dan taman bermain sangat dibutuhkan untuk menciptakan lingkungan fisik yang mendukung (HW, NN, DW).

\section{Referensi}

Ball, \& Bindler. (1995). Pediatric nursing: Caring for children. New Jersey: Pearson Education Inc.

Dinas Kesehatan Provinsi Riau. (2007). Profil kesehatan provinsi Riau 2007. Dinas Kesehatan Provinsi Riau, Sumatera Selatan.

Friedman. (2003). Family of nursing: Theory and practice. Connecticut: Appleton \& Lange.

Handayani, N. M. (2003). Ibu bekerja dan dampaknya bagi perkembangan anak. Diperoleh dari http://info.balitacerdas.com.

Markum, et al. (1991). Ilmu kesehatan anak jilid I. Jakarta: Bagian ilmu kesehatan anak.

National Institute of Child Health and Human Development Early Child Care Research Network. (2000). The Relation of care to cognitive and language development. Journal of Child Development, 71 (4), 977.

Potter, P., \& Perry, A. G. (2005). Fundamental keperawatan: Konsep, proses, dan praktek. Jakarta: EGC.

Redjeki, G.S. (2005). Kemampuan dan kepuasan ibu terhadap pendidikan kesehatan mengenai stimulasi perkembangan anak usia toddler (Master Tesis, tidak dipublikasikan). Universitas Indonesia, Jakarta.

Saadah, N. (2004). Penelitian perbedaan tumbuh kembang balita usia 3-18 bulan yang menggunakan buku KIA dengan yang tidak menggunakan buku KIA (Master Tesis, Universitas Airlangga, Surabaya, Jawa Timur). Diperoleh dari http://www.jiptunair.co.id.

Tanuwijaya, S. (2002). Kebutuhan dasar tumbuh kembang anak. Dalam: Narendra M, Sularyo S, Soetjiningsih, Suyitno H, Ranuh IGN, penyunting. Buku ajar tumbuh kembang anak dan remaja (Edisi ke-1). Jakarta: Sagung Seto. 